\title{
Pengaruh Gaya Kepemimpinan Dan Motivasi Kerja Terhadap Kinerja Pegawai Universitas Buana Perjuangan Karawang
}

\author{
Sihabudin ${ }^{1 *}$ \\ Universitas Buana Perjuangan Karawang \\ sihabudin@ubpkarawang.ac.id \\ *Penulis Koresponden \\ $\begin{array}{ll}\text { Diajukan } & : 7 \text { Juli } 2021 \\ \text { Disetujui } & : \text { 15 Agustus } 2021 \\ \text { Dipublikasi } & : \text { 30 Agustus } 2021\end{array}$
}

\section{ABSTRACT}

One of the variables that have a major effect on employee engagement is leadership style. In addition, one of the factors that influence employee efficiency is leadership. Since it is important to pay attention to two points at the top, it is important to pay attention to leadership style. Employee success is one of the most powerful variables in the workplace. Employees of Administration Universitas Buana Perjuangan Karawang, a total of 104 people, were studied from January to March 2020, with a total sample size of 82 people. The research employs a quantitative approach that is processed using the application SPSS 20. The data is collected through interviews, evaluation, and a Google Form Sample to deploy a questionnaire. Universitas Buana Perjuangan Karawang.

Keywords: leadership style, work motivation, employee performance

\section{PENDAHULUAN}

Saat ini, yang tidak dapat memisahkan semua aspek kehidupan dari aspek organisasi, manusia cenderung memiliki kodratnya sebagai makhluk sosial yang hidup dalam masyarakat. Hal ini berdampak pada kehidupan rumah tangga, organisasi masyarakat; Begitu juga saat memasuki dunia kerja. Sikap interaksi ini akan terus menjadi bagian dari suatu organisasi. Organisasi adalah alat yang sengaja dibentuk atau diciptakan untuk membantu orang memenuhi dan mencapai tujuan (Ahmad Sobirin P, 2020).

Dalam mencapai tujuan Organisasi, setiap Organisasi membutuhkan sumber kekuatan untuk mencapai tujuannya. Sumber kekuasaan meliputi sumber kekuatan alam, sumber keuangan, sumber kekuatan ilmu pengetahuan, teknologi, dan kekuatan manusia itu sendiri. Di antara sumber tenaga, sumber sumber yang terpenting adalah sumber tenaga manusia (Ahmad Sobirin P, 2020).

Sumber kekuasaan manusia merupakan aset organisasi yang paling penting dan menjadikan fungsi organisasi sumber kekuasaan lainnya (Sesnaingtiyas, 2009). Tanpa sumber tenaga manusia, sumber tenaga lain akan menganggur dan kurang membantu dalam mencapai tujuan organisasi. Untuk mencapai tujuan organisasi, tentunya karyawan dituntut untuk dapat memaksimalkan kinerjanya. Kinerja pegawai merupakan hal penting yang perlu diperhatikan bagi organisme karena dapat mempengaruhi tujuan organisasi dalam persaingan global yang sering berubah (Ahmad Sobirin P, 2020). Kinerja lebih baik dilihat dari hasil yang diperoleh sesuai standar organisasi.

Menurut (Ahmad Sobirin P, 2020), kinerja adalah hasil yang diperoleh suatu organisasi baik yang berorientasi pada laba maupun tidak berorientasi pada laba yang dihasilkan selama periode yang ditentukan. Siapa yang bisa melihat kinerja yang lebih baik dari hasil yang diperoleh Organisasi standar. Kinerja merupakan gambaran tingkat pencapaian kegiatan dalam mewujudkan tujuan dan sasaran. Organisasi bagi kinerja merupakan salah satu fungsi yang sangat berpengaruh dalam mencapai tujuan perusahaan disamping fungsi dan faktor lainnya. 
Pengelolaan sumber daya manusia adalah suatu proses yang meliputi evaluasi kebutuhan SDM, mengajak masyarakat untuk memenuhi kebutuhan tersebut, mengoptimalkan pemanfaatan sumber daya manusia yang membutuhkannya dengan memberikan penugasan yang intensif dan tepat kepada sesuai dengan kebutuhan dan tujuan organisasi dimana sumber kekuasaan manusia itu berada. (Widodo, 2015).

Untuk mencapai tujuan berlian, tentunya karyawan selalu dituntut untuk memaksimalkan kinerja terbaiknya. Terdapat faktor-faktor negatif yang dapat menurunkan kinerja pegawai, di antaranya adalah menurunnya keinginan pegawai untuk mencapai prestasi kerja, kurangnya waktu dalam penyelesaian pekerjaan yang kurang patuh terhadap aturan, yang dampaknya berasal dari lingkungan, co-working. - Pekerja juga mengalami penurunan semangat kerja, dan tidak ada. Contoh dijadikan sebagai acuan dalam mencapai prestasi kerja yang baik. Peran seorang pemimpin adalah menjadi gatekeeper dalam membangun moral bawahannya untuk mencapai tujuan perusahaan. Inilah beberapa penyebab turunnya kinerja karyawan (Byran, 2014).

Universitas Buana Perjuangan Karawang dengan jumlah pegawai 104 orang dan 11 unit/bidang tugas yang mempunyai tugas mengkoordinasikan perumusan teknis dan perencanaan, pelaksanaan pelayanan, dan pembinaan administrasi keuangan di Universitas Buana Perjuangan Karawang.

Tabel 1. Kinerja Pegawai Universitas Buana Perjuangan Karawang

\begin{tabular}{|l|c|c|c|}
\hline \multicolumn{1}{|c|}{ Unit Kerja } & Target & Capaian & Persentase (\%) \\
\hline Academik & 2000 & 1973 & 98,65 \\
\hline Bagian Umum & 300 & 250 & 83,33 \\
& & & \\
\hline Keuangan & 2658 & 2470 & 92,92 \\
\hline Kepegawaian & 201 & 170 & 84,58 \\
\hline Kemahasiswaan & 5615 & 5500 & 97,95 \\
\hline UPT Bahasa & 12 & 11 & 91,67 \\
\hline Marketing and Dokumentasi & 300 & 250 & 83,33 \\
\hline Alumni & 350 & 310 & 88,57 \\
\hline Kerjasama & 350 & 300 & 85,71 \\
\hline Pusat Data dan Informasi & 340 & 290 & 85,29 \\
& & & \\
\hline Laboratorium & 60 & 37 & 61,66 \\
\hline Total & 12.186 & 11.784 & 953.66 \\
\hline
\end{tabular}

Sumber: Universitas Buana Perjuangan Karawang (2019)

Dari Tabel 1 diatas dapat diketahui bahwa kinerja pegawai bagian tata usaha pada Universitas Buana Perjuangan Karawang pada setiap bagian atau unit kerja terletak pada realisasi pencapaian hasil kerja paling bawah khususnya pada bagian urusan Laboratorium persentasenya rendah, yaitu $61 \%$. Nilai $N$ guna penyajian hasil kerja karyawan antara 55\% sampai dengan $65 \%$ termasuk dalam peruntukan kurang baik.

\section{TINAJAUAN PUSTAKA}

\section{Motivasi dan Disiplin Kerja}

Menurut Veithazal motivasi kerja adalah kumpulan sikap dan nilai yang mengilhami individu untuk melakukan tindakan sesuai dengan tujuannya sendiri, dan sikap serta nilai ini memberi individu kemampuan untuk mendukung individu (Veithazal Rivai, 2011) Melakukan tindakan untuk mencapai suatu tujuan. Indikator motivasi kerja sebagai berikut: (1) Achievement of Needs merupakan dimensi yang terdiri dari empat indikator. Persyaratan untuk mengembangkan 
kreativitas (b) Persyaratan untuk meningkatkan keterampilan (c) Persyaratan untuk mencapai tingkat keberhasilan yang maksimal (d) Persyaratan untuk beroperasi secara efektif dan efisien (2) Dimensi Kebutuhan Afiliasi didefinisikan oleh tiga kriteria berikut Dan kami berkolaborasi Dan (3) tiga tanda membentuk dimensi kehausan akan kekuasaan. Adapun disiplin kerja pandangan (Simamora, 2014) merupakan proses mengoreksi atau mendisiplinkan pegawai yang melanggar aturan atau prosedur. Dalam bahasa lain pengendalian diri dan penerapan yang konsisten dari karyawan, dan ini mencerminkan tingkat keparahan tim kerja di dalam bisnis. Perilaku disiplin menentukan hukuman yang dijatuhkan kepada karyawan yang tidak mematuhi norma-norma yang ditetapkan. Tindakan disipliner (Hasibuan, 2013) yang efektif difokuskan pada kesalahan karyawan, bukan pada karyawan tertentu " Indikator disiplin kerja antara lain sebagai berikut: Identik: (1) Sikap (a) kehadiran dan (b) pikiran dan tindakan sebagai konsekuensi dari persepsi mereka saat memenuhi tanggung jawab dan aturan di perusahaan dengan fasilitas yang digunakan dengan baik dan tersedia. (2) Kode adalah seperangkat aturan yang mengatur apa yang boleh dan tidak boleh dilakukan seorang karyawan selama bekerja di perusahaan, dan sebagai standar sikap, terdiri dari: (a) Kesesuaian adalah rasa kepatuhan karyawan terhadap peraturan karyawan perusahaan. (b) Mematuhi praktik bisnis perusahaan. (3) Tanggung jawab meliputi hal-hal berikut: (a) kapasitas untuk melaksanakan tanggung jawab; dan (b) kepatuhan terhadap peraturan perusahaan. Jumlah pekerjaan kualitatif dan kuantitatif yang dilakukan seorang karyawan saat melaksanakan kewajiban yang diberikan kepadanya merupakan definisi yang dikemukakan oleh (Mangkunegara, 2016). Sedangkan dimensi dan indikator yang mengatur kinerja karyawan menentukan bahwa kinerja karyawan mencakup berbagai aspek (Robbins, 2010) kepatuhan mereka terhadap kriteria yang ditetapkan; (a) kemampuan dan (b) presisi. (2) Beban kerja adalah jumlah keluaran yang dinyatakan dalam satuan atau siklus kegiatan yang diselesaikan. (a) bakat dan (b) ketangkasan. (3) Produktivitas didefinisikan sebagai tingkat di mana tugas dilakukan sesuai jadwal dan dengan hasil yang baik. Kepuasan (a) dan Akurasi (b). (4) Efisiensi mengacu pada penyelesaian tugas yang tepat waktu, dan ketepatan waktu menunjukkan keberhasilan pengguna alokasi waktu. (a) Keberhasilan dan (b) Keandalan. dan (5) kemandirian dan inisiatif pegawai dalam melaksanakan pekerjaan tanpa menunggu instruksi pimpinan; (a) Inisiatif dan (b) Tanggung Jawab. Kelima faktor ini dapat digunakan untuk menilai tingkat kinerja karyawan.

\section{METODE PENELITIAN}

Teknik verifikatif deskriptif digunakan dalam penelitian ini dalam hubungannya dengan pendekatan kuantitatif. Pendekatan deskriptif (Sugiyono, 2016) teknik analisis data yang melibatkan penggambaran atau pengkarakteristikan data yang diperoleh untuk mencapai temuan atau generalisasi yang dapat diterima secara luas. Teknik lain adalah validasi, yang merupakan proses penelitian berbasis positivis yang melibatkan pemeriksaan populasi atau sampel tertentu dan pengumpulan data menggunakan instrumen penelitian. Ini adalah statistik kuantitatif yang digunakan untuk menguji hipotesis. Untuk variabel bebas (motivasi dan disiplin kerja) dan variabel terikat (kinerja karyawan) dalam penelitian ini, digunakan metode deskriptif untuk memahami secara sistematis penjelasan variabel-variabel tersebut, dan metode verifikatif digunakan untuk mengukur fenomena dalam penelitian dengan menggunakan metode berikut . Alat analisis statistik.

\section{HASIL DAN PEMBAHASAN}

Berdasarkan hasil penelitian pada tabel 2 dapat diketahui bahwa gaya kepemimpinan pada Universitas Buana Perjuangan Karawang dengan tiga dimensi, 15 indikator, dan 15 peran, dengan total skor 3,624 yang berada pada rentang skala sebesar 2.460 - 3.690 dengan kriteria tinggi.

Table 1. Rekapitulasi Indikator Variabel Gaya Kepemimpinan

\begin{tabular}{|l|l|l|l|}
\hline No. & Indikator & Jumlah Skor & Kriteria \\
\hline 1 & Selalu Melayani & 251 & Cukup Tinggi \\
\hline 2 & Keputusan & 249 & Cukup Tinggi \\
\hline 3 & Tergantung pada Kekuatan & 220 & Cukup Tinggi \\
\hline 4 & Mendekati & 239 & Cukup Tinggi \\
\hline 5 & Perhatikan Kesejahteraan & 256 & Cukup Tinggi \\
\hline
\end{tabular}


Owner: Riset \& Jurnal Akuntansi

e-ISSN : 2548-9224 |p-ISSN : 2548-7507

Volume 5 Nomor 2, Agustus 2021

DOI : https://doi.org/10.33395/owner.v5i2.573

\begin{tabular}{|l|l|l|l|}
\hline 6 & Selalu Libatkan Bawahan & 247 & Cukup Tinggi \\
\hline 7 & Memotivasi Karyawang & 249 & Cukup Tinggi \\
\hline 8 & Menerima Saran, Pendapat dan Kritik & 229 & Cukup Tinggi \\
\hline 9 & Bekerja Sama & 227 & Cukup Tinggi \\
\hline 10 & Aktif dalam Segala Bentuk Aktivitas & 225 & Cukup Tinggi \\
\hline 11 & Aturan & 252 & Cukup Tinggi \\
\hline 12 & Menyelesaikan Pekerjaan & 234 & Cukup Tinggi \\
\hline 13 & Tanggung Jawab & 227 & Cukup Tinggi \\
\hline 14 & Diskusi & 258 & Cukup Tinggi \\
\hline 15 & Memercayai & 261 & Cukup Tinggi \\
\hline \multicolumn{2}{|l}{ Total Skor } & 3.624 & Cukup Tinggi \\
\hline \multicolumn{2}{|l}{ Rata - Rata Skor } & 241 & Cukup Tinggi \\
\hline
\end{tabular}

Kepemimpinan di Universitas Buana Perjuangan Karawang sudah baik. Sedangkan indikator tertinggi dengan skor 261 berada pada rentang skala 214-280, dengan kriteria keyakinan pernyataan relatif tinggi. Artinya pemimpin memiliki kepercayaan diri yaitu cukup tinggi terhadap petugas yang disebutkan. Pada saat yang sama, nilai terendah pada indikator tergantung pada kekuatannya.

Motivasi belajar kerja memiliki dua dimensi berdasarkan variabel, yaitu 15 indikator dan 15 pernyataan. Perolehan skor 3,625 berada pada rentang skala 2460-3690, dengan kriteria cukup tinggi.

Table 2. Rekapitulasi Indikator Variabel Motivasi Kerja

\begin{tabular}{|l|l|l|l|}
\hline No. & Indikator & Jumlah Skor & Kriteria \\
\hline 1 & Mengeluh Di Tempat Kerja & 219 & Cukup Tinggi \\
\hline 2 & Sukses di Tempat Kerja & 241 & Cukup Tinggi \\
\hline 3 & Melakukan Pekerjaan dengan Baik & 251 & Cukup Tinggi \\
\hline 4 & $\begin{array}{l}\text { Kesempatan untuk Belajar Bertanggung } \\
\text { Jawab }\end{array}$ & 253 & Cukup Tinggi \\
\hline 5 & Kesempatan untuk Belajar & 266 & Cukup Tinggi \\
\hline 6 & Memperoleh Prestasi & 243 & Cukup Tinggi \\
\hline 7 & Memperoleh Hibah & 245 & Cukup Tinggi \\
\hline 8 & Mengikuti Pelatihan & 250 & Cukup Tinggi \\
\hline 9 & Memperoleh Gaji/Upah & 247 & Cukup Tinggi \\
\hline 10 & Memperoleh Kepuasan Pendapatan & 230 & Cukup Tinggi \\
\hline 11 & $\begin{array}{l}\text { Hubungan Antar Karyawan Berjalan } \\
\text { dengan Baik }\end{array}$ & 228 & Cukup Tinggi \\
\hline 12 & Lingkungan Kerja & 240 & Cukup Tinggi \\
\hline 13 & Bekerja dengan Sangat Baik & 222 & Cukup Tinggi \\
\hline 14 & Mengembangkan Keterampilan & 241 & Cukup Tinggi \\
\hline 15 & Kenyamanan & 249 & Cukup Tinggi \\
\hline Total Skor & 3.850 & Cukup Tinggi \\
\hline Rata - Rata Skor & 251 & Cukup Tinggi \\
\hline
\end{tabular}

Motivasi kerja di Universitas Buana Perjuangan Karawang menunjukkan tingkat yang cukup tinggi. Sedangkan indikator tertinggi dengan skor 254 berada pada rentang skala 214-280, kriteria yang relatif tinggi pada pernyataan memberikan gambaran. Artinya, karyawan selalu memberikan ide-ide yang cocok untuk kantor. Sedangkan skor rendah adalah indikator ketepatan waktu pelaksanaan 221 berada pada rentang skala 214-280 dengan kriteria dangkal. Artinya, karyawan kurang termotivasi. 
Berdasarkan hasil penelitian, variabel kinerja pegawai memiliki empat dimensi yang terdiri dari 15 indikator dan 15 pernyataan. Total skor 3.643 berada pada rentang skala 240 - 3.690 dengan kriteria relatif tinggi.

Table 3. Rekapitulasi Indikator Variabel Kinerja Pegawai

\begin{tabular}{|c|l|c|c|}
\hline No & \multicolumn{1}{|c|}{ Indikator } & Jumlah Skor & Kriteria \\
\hline 1 & Datang Tepat Waktu & 253 & Cukup Tinggi \\
\hline 2 & Tidak Menunda Pekerjaan & 247 & Cukup Tinggi \\
\hline 3 & Menangani Keadaan Darurat di Tempat Kerja & 242 & Cukup Tinggi \\
\hline 4 & Menjaga Kerapihan Pekerjaan & 231 & Cukup Tinggi \\
\hline 5 & Teliti dalam Menjalankan Pekerjaan & 252 & Cukup Tinggi \\
\hline 6 & Mengerjakan Tugas & 252 & Cukup Tinggi \\
\hline 7 & Inisiatif & 236 & Cukup Tinggi \\
\hline 8 & Bekerja Sama & 252 & Cukup Tinggi \\
\hline 9 & Memberikan Bantuan & 240 & Cukup Tinggi \\
\hline 10 & Kordinasi & 247 & Cukup Tinggi \\
\hline 11 & Komunikasi & 231 & Cukup Tinggi \\
\hline 12 & Memberikan Ide & 254 & Cukup Tinggi \\
\hline 13 & Mampu Melakukan Perkerjaan & 240 & Cukup Tinggi \\
\hline 14 & Mudah dan Teliti & 245 & Cukup Tinggi \\
\hline 15 & Mengerjakan Tugas dengan Cepat $\quad$ Total Skor & 3.643 & Cukup Tinggi \\
\hline \multicolumn{2}{r|}{ Rata - Rata Skor } & 242 & Cukup Tinggi \\
\hline
\end{tabular}

Hal itu menunjukkan bahwa kinerja pegawai di Universitas Buana Perjuangan Karawang sudah baik. Sedangkan indikator tertinggi dengan skor 254 berada pada skala 214-280, dengan kriteria cukup baik pada pernyataan memberikan gambaran. Sebaliknya skor terendah terdapat pada indikator melaksanakan tugas dengan cepat dengan skor 221 berada pada rentang skala 214 sampai dengan 280 dengan kriteria cukup baik artinya staf administrasi Universitas Buana Perjuangan Karawang dapat melaksanakan kesesuaian dalam menjalankan tugasnya. Pergi keluar dan selesaikan tugas mereka dalam pekerjaan.

Pengaruh gaya kepemimpinan secara parsial terhadap kinerja pegawai Hasil penelitian di bawah ini menunjukkan bahwa gaya kepemimpinan berpengaruh terhadap kinerja pegawai pada Universitas Buana Perjuangan Karawang. Terbukti dengan nilai 0,025 atau 2,56\%. Terbukti bahwa gaya kepemimpinan berhubungan dengan kinerja karena gaya kepemimpinan pegawai akan meningkatkan kinerja untuk melaksanakan tugas pekerjaan.

Berdasarkan hasil angket pengelolaan data dengan menggunakan SPSS 20 diperoleh nilai koefisien garis masing-masing variabel gaya kepemimpinan (X1) dan motivasi kerja (X2) terhadap kinerja karyawan (Y).

Berdasarkan Tabel 5 diperoleh nilai koefisien lintasan variabel Gaya Kepemimpinan (X1) terhadap Kinerja Pegawai (Y) sebesar -0,016. Hal ini ditunjukkan tidak adanya pengaruh langsung gaya kepemimpinan (X1) terhadap kinerja karyawan (Y) sebesar -016. Sehingga diperoleh nilai persamaan $\mathrm{Y}=-, 016 \mathrm{X} 1$

Berdasarkan hasil perhitungan koefisien diperoleh nilai sebesar 0,0064\%, variabel kinerja pegawai (Y) dipengaruhi secara langsung oleh variabel gaya kepemimpinan (X1) yaitu sebesar 2,56. Sedangkan sisanya $(100 \%-2,56=97 \%)$ dipengaruhi oleh faktor lain.

Pengaruh secara parsial motivasi kerja terhadap kinerja pegawai Hasil penelitian di bawah ini menunjukkan bahwa motivasi kerja berpengaruh terhadap kinerja pegawai pada Kantor Universitas Buana Perjuangan Karawang yang dibuktikan dengan nilai sebesar 0,383 atau 383\%. 
Motivasi kerja mempengaruhi kinerja. Ada atau tidak adanya motivasi akan mempengaruhi kinerja pegawai yang tidak akan tercapainya tujuan penugasan kerja.

Table 4. Besaran Pengaruh

\begin{tabular}{|c|c|c|c|}
\hline \multirow{3}{*}{ Variabel } & Analisis Interachievement Path & Kalkulasi & Besaran Pengaruh \\
\cline { 2 - 4 } Motivasi & Pengaruh Langsung Terhadap Y & $0,621^{2}$ & 0,385 \\
\cline { 2 - 4 } Kerja (X1) & $\begin{array}{c}\text { Tidak Ada Pengaruh Langsung X2 } \\
\text { Terhadap Y }\end{array}$ & $\begin{array}{c}0,621 \times(-0,008) \times \\
0,570\end{array}$ & $-0,002$ \\
\cline { 2 - 4 } & \multicolumn{2}{|c}{ Jumlah } & 0,383 \\
\hline
\end{tabular}

\section{KESIMPULAN}

Berdasarkan penelitian dan pembahasan yang telah dilakukan di Universitas Buana Perjuangan Karawang, mengenai gaya kepemimpinan dan motivasi kerja terhadap kinerja pegawai, dapat diketahui bahwa hasil penelitian tentang gaya kepemimpinan, motivasi kerja, dan kinerja pegawai administrasi pada Universitas Buana Perjuangan Karawang berada pada kriteria cukup tinggi, artinya responden menyatakan gaya kepemimpinan sudah berjalan dengan baik. Hal ini terlihat dari jawaban 15 indikator dan 15 pernyataan dengan kriteria yang relatif tinggi.

Terdapat pengaruh negatif parsial gaya kepemimpinan dan motivasi kerja terhadap kinerja karyawan, dimana gaya kepemimpinan berpengaruh negatif terhadap kinerja sebesar -0,008 atau sebesar $006 \%$. Dan terdapat pengaruh positif secara parsial motivasi kerja terhadap kinerja karyawan sebesar 0,619 atau $385 \%$.

\section{REFERENSI}

Achmad Sobirin , P. (2020, July 17). Organization and Organizational Behavior Module . Taken back from respotory.ut.ac.id: respotory.ut.ac.id/pdf

Anwar Prabu Mangkunegara . (2013). Management Resources Power Man Bandung: Alfabeta Publisher . Seventeenth Printing . Jakarta: PT. EarthAksara

Bukit, B.dkk. ( 2017). Pengemb wishful Source Power Man Theory of dimensional measurement and implementation in the Organization.

Byran, JT (2014). Influence Style Kempemimpinan and Motivation To Performance Employees at PT. Bank Negara Indonesia Tbk (Regional Sales Manado). Acta Diurna Journal, 1 -20.

Edy Sutrisno . ( 2014). Management Resources Power Man. Jakarta : Kencana Feriyanto , A., \& Shyta, ET (2015). Introduction to Management (3 In 1) . Kebumen :

Hasibuan, Malayu.S.P. ( 2013) Manajemen Sumber Daya Manusia, Jakarta: PT.Bumi Aksara

Mangkunegara , AAAP (2016). Management Resources Power of Man Company. Bandung: PT Remaja Rosdakarya.PrenadaMediaGroup ..

Mardiyanti , D., Mulyantini , n., Herlina , E., Economics , F., Galuh , U., Banjar, A., Banjar, TA ( 2019). EFFECT OF EMPLOYEE ACHIEVEMENT ASSESSMENT ON EMPLOYEE WORK MOTIVATION ( Study at PT Te Telekomunikasi Indonesia, Tbk Banjar Area). 1 (September), 1-7.

Rifkhan. (2018). Factors - Factors That Affect the Performance Lecturer University of Pamulang. Journal of Business and Accounting, 3 (2), 358-373.

Rivai vethizal (2011) Manajemen Sumber Daya Manusia untuk Perusahaan Teori ke Praktek, Jakarta :Raja Grafindo Persada.

Rivai vethizal (2016) Manajemen Sumber Daya Manusia untuk Perusahaan Teori ke Praktek, Jakarta :Raja Grafindo Persada

Robbins, Stephen. P. (2010). Manjemen. Edisi Kesepuluh. Jakarta: Erlangga.

Scientific, p. 92017). With Work Motivation as a Mediating Variable (Empirical Study at KPP Pratama Karanganyar )

Simamora, H. (2014). Membuat Karyawan Lebih Produktif dalam Jangka Panjang (Manajemen SDM), Yogyakarta: STIE YKPN.

Sugiyono. (2012). Metode Penelitian Kombinasi (Mixed Methods). Alfabeta. 
Owner: Riset \& Jurnal Akuntansi

e-ISSN : 2548-9224 |p-ISSN : 2548-7507

Volume 5 Nomor 2, Agustus 2021

Sugiyono. (2016). Metode Penelitian Pendidikan Pendekatan Kuantitatif, Kualitatif, dan R\&D. Alfabeta.

Wibowo, M. Phi. (2017). Performance management (et.12). Raja Grafindo Persada

Zonyfar, C., Maharina, Zayn, M. \& Barack, E., 2020. Student Enrollment: Data Mining Using Naïve Bayes Algorithm. Journal of Advanced Research in Dynamical and Control Systems, pp. 1077-1083. 